\title{
A Study on Empathy, Credibility, and Political Attitude in Social Media: Focused on the Relationship between Empathetic Intention and the Motivation of Belonging on Intended Pro-Social and Political Behavior
}

\author{
SeoYoung Lee ${ }^{1}$, Sang Hee Kweon ${ }^{2 *}$ \\ ${ }^{1}$ Graduate School of Information, Yonsei University, Seoul, Korea \\ ${ }^{2}$ Department of Mass Communication \& Journalism, Sungkyunkwan \\ University, Seoul, Korea \\ Email: "skweon@skku.edu
}

Received April 16 $6^{\text {th }}, 2013$; revised May $26^{\text {th }}, 2013$; accepted June $6^{\text {th }}, 2013$

\begin{abstract}
Copyright $\odot 2013$ Seo-young Lee, Sang Hee Kweon. This is an open access article distributed under the Creative Commons Attribution License, which permits unrestricted use, distribution, and reproduction in any medium, provided the original work is properly cited.
\end{abstract}

\begin{abstract}
This study explores the relationship how SNS through empathetic intentions and motives affect political participation and foster positive attitudes. In addition, this research explores how online and offline interaction affects attitudes in political participation. The theoretical background of the research is based on the theory of planned behavior, in which the behavior of individuals is determined by attitudes towards behavior, and the subjective norms that influence intended behavior. Depending on how much time is spent on personal online activities, you can predict offline behavior through online attitudes, which can help to increase the explanatory power of the theory of planned behavior. In this study, there is a verification of offline political action related to the attitudes formed through social media. Social network service (hereafter SNS) could have important implication for modern society as a predictive tool. The research was conducted on 291 members of an SNS community and based on the survey data gathered, a hierarchical regression analysis was applied. The analysis was found to significantly predict the behavioral tendency of the subjects to cooperate and share information online when there is an intent and motive towards personal empathy. Online cognitive behavior control shows that the higher level of information sharing and trust, the higher the offline intent to participate in political action. Finally, there is a high correlation between online and offline political attitudes. The more positive the political attitudes, either online or offline, the more intent to participate in offline political action.
\end{abstract}

Keywords: SNS; Trust; Empathy; Pro-Social Behavior; Political Participation

\section{Introduction}

The SNS (social network service) is a public space and at the same time a private space for self-expression. Through SNS, people have an increased opportunity to express themselves and expose themselves to the public in which in turn deepens the level of communication and self-disclosure, so that it promotes honest and sincere interaction. This can be said to be empathy (Stern, 2002).

Researchers define empathy in various different ways. They also focus on very different aspect of empathy in their research (Eisenberg \& Fabes, 1990; Eisenberg \& Miller, 1987; Wispé, 1986). The theoretical construct of empathy that has been used in previous studies include diverse terms such as cognitive empathy, emotional contagion, empathic accuracy, self-other overlap, and sympathy (Preston \& Hofelich, 2011). In addition, according to the theoretical construct of empathy that researcher have adopted, the subject of studies also vary greatly, for example, expressive stereotypical behavior of participants, emo-

${ }^{*}$ Corresponding author. tional response and helping behavior, empathy regarding accurate inferences about the thoughts and feelings of subjects, matching degrees of self-concept and other-concept, etc. (Batson, Sager et al., 1997; Davis, Conklin, Smith, \& Luce, 1996; Galinsky \& Moskowitz, 2000; Simpson, Orina, \& Ickes, 2003).

Even though the concepts construed and subject matters vary among researchers, empathy can be divided into two broad categories, cognitive empathy and emotional empathy. This is based on the research focus which naturally falls between these two aspects of empathy. Eisenberg and Miller (1987) who focused on the emotional aspect defined the empathy as "understanding the emotional states of others, and experiencing the same emotional state". Ickes (1993) who focused on the cognitive aspect, defined empathy as "the ability to accurately infer the content of the thoughts and feelings of others". In addition, Batson (1987) defined empathy as "one's perception of others welfare state and consistent others-oriented emotional reactions." Galinsky, Ku and Wang (2005) defined it as a "Process of imagining the self and the world from an others-oriented perspective". Looking at these definitions, researchers typically 
approach empathy as either cognitive empathy or emotional empathy.

On the other hand, there were some attempts made to comprehensively cover the topic that do not distinguish between cognitive empathy and emotional empathy. Regan and Totten (1975) claim that taking the perspective of others causes a change in information processing which would impact on the sentiment to share.

Davis (1983) conceptualized empathic interest as comprised of four sub-factors; empathic concern, perspective taking, fantasy, and personal distress. Recently, Hodges and his colleagues (2010) conducted research on empathic concern and sought to define the components of empathy and the accuracy thereof simultaneously in a single experiment.

Therefore, we need to consider carefully social behavior that appears differently depending on empathetic intention. These are necessary considerations when trying to identify a pattern concerning high empathy and pro-social behavior. Because empathy reflects interpersonal situations between individuals and others, SNS use can be seen to reflect that intention to empathize with other people. This is apparent in the exchange of information with others or in any situation in which community participants talk and exchange opinions.

In this study we attempt to verify perception through asking questions about the purpose of the SNS connections and the characteristics of SNS discourse. Therefore, in this study, we will measure empathetic intent towards others via SNS.

\section{Theoretical Background}

\section{Theory of Planned Behavior}

The purpose of this study is to measure the correlation between empathy experience and political expression from a point of view of theory of planned behavior on the premise that SNSmediated experience of empathy has a positive impact on interpersonal trust and social trust.

According to the theory of planned behavior (TPB), human behavior is determined by the positive attitudes towards executing certain behavior and by the evaluation of actions from others who are important to the actor. That is, in the theory of planned behavior, the explanation about an individual's specific behavior is modeled as the causality of an attitude toward intended behavior, subjective norms, and perceived behavioral control that affects behavioral intent, and finally the behavior intent that drives specific behavior (Ajzen, 1985). The specific factors that comprise the theory of planned behavior are attitudes that affect behavioral intent, subjective norms, perceived behavioral control, and behavioral factors. Attitudes means the assessment made on a specific act of individual and comprise of the potential of action taken thereby appearing subjective, and emotional recognition.

In addition, subjective norms are a kind of social pressure created when somebody initiates specific behavior considering how other people the actor considers important would assess that behavior and if the actor can accept that reaction.

Perceived behavioral control means self-awareness of any action he or she can performs and the extent to which those actions are being carried out under one's own control. Lastly behavioral intent means the expression of willingness to do one's intended behavior (Ajzen, 1985).

Online communication effect or pattern is a condition that is determined by a user's prejudice and orientation on community activities. This has emerged in cognitive psychology, as $\mathrm{O}_{1}-\mathrm{S}-\mathrm{O}_{2}-\mathrm{R}$ (Orientation -Stimuli-Orientation $_{2}$-Responses, Markus \& Zajonc, 1985) model which says that according to social background, structural characteristics, the recognition and synchronization characteristics of individual, and the acceptance state regarding personal messaging activities, choices are induced. It is a very useful model to explain on-line news selection, sustainable consumption, community activities, and comments activities.

$\mathrm{O}_{1}-\mathrm{S}-\mathrm{O}_{2}-\mathrm{R}$ model added complex orientation $\left(\mathrm{O}_{1}, \mathrm{O}_{2}\right)$ to traditional psychology model of stimulus-response (SR). Prior to stimulus ( $\mathrm{S}$ ), the use of media or political inclination becomes the first orientation $\left(\mathrm{O}_{1}\right)$ of the acceptor. This includes demographic variables, dependency tendency of online users, etc. The second orientation $\left(\mathrm{O}_{2}\right)$ that appears after the use of Internet act as a moderator and political communication through online activities represent the message type, perceptions, and attitudes etc. Finally, reaction (R) corresponds to the variables for online political action.

As described in TPB, theoretically perceived behavioral controls are based on self-efficacy theory (Bandura, 1977). Bandura (1977) described self-efficacy as self-confidence that individuals believe he or she can successfully perform the behavior for specific results. When this is applied to the political behavior, political self-efficacy can be seen as a person's beliefs about one's ability to affect the political system. Likewise in previous studies it is reported that people who feel higher political efficacy believe that they can influence their political system or political process and appreciate political participation and intend actual participation more than those who do not (Kang, 2004). Considering these points, it can be anticipated that higher the political efficacy, the higher the intent to participate politically.

If we apply the theory of planned behavior (TPB) an individual's participation in politics; attitudes, subjective norms, and political efficacy regarding political participation, influence the intent to participate politically and again this will influence actual political participation.

For example, when individual forms a positive attitude toward political participation and when individuals received the pressure for political participation from their surroundings, he or she will participate in voting, discussion, or political campaigns.

Thus, the political participation of individuals can be understood as a planned action. Based on these points, in this study we applied the theory of planned behavior to SNS and we'd like to explore whether attitudes, subjective norms, and political efficacy regarding political participation that is formulated online will predict real-world offline intent to participate politically.

\section{Empathetic Intention and Attitude towards Political Participation}

Research that says empathy causes pro-social behavior is a consensus that has accumulated in the field of social psychology over a long period of time. In the study of $\mathrm{Ku}$, Wang, and Galinsky (2010), the perspective of the participants were manipulated to take the point of view of the elderly or to maintain an objective perspective. After that participant's conservativeness was measured by asking questions such as, the degree in which they favor of homo-sexual marriage, the degree in which 
they favor exposure to scenes of sexual activity in over-the-air broadcast, etc., through a questionnaire. In addition, the participants also read a scenario that contained a description that is difficult to interpret and containing ambiguous behavior, then they asked the participants to determine the degree to which the scenario protagonist to relied on others. As a result, the participants with elderly perspective had higher conservative tendency than the participants in the controlled environment maintaining an objective perspective and had a higher tendency to judge that the protagonist in the scenario is less dependent. In another research, after manipulating participants' perspective in the same manner, the time required for participants to walk to elevator from the research lab was measured after finishing the experiment. As a result, participants with the elder's perspective walked more slowly than participants in the controlled environment, taking more time to arrive at the elevator. These results suggest that if someone has cognitive empathy for others, his or her behavior occurs in a manner consistent to stereotypes of the empathetic object, however attitudes actually form in the opposite direction to the stereotypes. Therefore, when one has interaction with certain objects of his or her stereotype (for example, black or elderly) behavioral control will happen in a socially desirable way. In other words, cognitive empathy helps pro-social expression.

In the study of Batson et al. (1997), participants were randomly assigned to a group in which they imagine what the character of a scenario would feel in the situation depicted in an article (high-empathy), and a group in which they read the same scenario in a highly objective way (low-empathy). After that, the participants read the scenario presented in the form of an interview with the head of household of the girl who lost her parents in a car accident.

Analyzing the results, for the empathy emotions (26 adjectives such as "pitiful", "thought provoking", "touching", etc.) that participants experienced while reading the scenario, and the time that participants reported for how much they can volunteer to help the scenario protagonist, participants who read the scenario while imagining how the protagonist would feel reported strong empathetic emotions and applied more time to spend in volunteer activities compared to participants who read the scenario with an objective attitude. These results appear consistently regardless of introducing the scenario protagonist as a student at the same school with the participants or as a student at a rival school to the participants. Therefore in this study, we'd like to understand the impact of online and offline attitudes towards political participation that appear through sharing emotions with others from the perspective of emotional empathy.

Table 1 Sympathy in relation to attitude and intention towards political participation is located in the appendix.

\section{Trust and SNS from the Perspective of Social Capital}

Personal behavior is not just determined by personal characteristics. Humans are basically social animals and are influenced by our relationships with others, the social context and various other factors that occur within that. Therefore, human social resources can be seen to be the primary means for individuals to maintain a certain level of welfare and to achieve goals. Putnam (1995) defined social capital as norms, trust, and the network that facilitates coordination and cooperation for the mutual benefit of the members of society.
Social capital refers to something that exists within human relationships compared to physical capital and human capital that enables production. But social capital does have something in common with physical capital and human capital in having a role to increase production. Social capital is very important because it has the role of enabling social order by granting behavioral norms and common cultural identity shared among members of society. The role of social capital then can be summarized into following three factors. First, the role of information sharing, it enables formal and informal institutions to provide accurate information. Second, the role of coordination is to enable interaction between individual to restore trust among members. Finally, the role of creating external effects is through collective decision-making.

Trust is the most basic element that comprises social capital and it is a subjective belief formed through a relationship between person and the target of trust (Fukuyama, 1999). On trust, Giddens (1990) claimed that trust is a property like resources that provides guidance to the behavior of individuals as well as essential element to maintain and develop society. Such interpersonal trust means a set of attitudes that people have toward fellow citizens which can be instituted and accumulated through a process of repetition and organization. When we consider such factors, it seems obvious that social capital has a great affect on society as a whole by improving the level of trust between community members.

Therefore, we need to pay attention to the role of SNS as it gives opportunities to expand social capital for individuals. The reason for this is that social capital expanded through SNS allows each individual to affect the outside world through collective decision-making. In this study, as a extension to the role that SNS plays in expanding social capital, we will also explore how SNS influences individual's intention to engage in offline political behavior, with an especial focus on the role of trust that is formed within SNS communities.

Prior to discussing social capital we need to first understand networks. Interconnection or networking is a basic premise of forming human community. Networks often provide the mechanisms that lead to the realization of a group's common interests, such as political and economic development of the group at a collective level (Brehm \& Rahn, 1997). The reason networks form the core of discussion in social capital related discussions is because networks have become the basis for the externalization of social capital. For example, interconnection makes possible for individuals to take on essential roles in community activities by facilitating the spread of information, shared responsibility, trust within the group, and external direction.

Likewise, another reason understanding networks are important in discussing social capital is because accrued social capital generates certain behavioral outcomes. One of these outcomes, as it has been reported in a study, is that as social capital increases, the social and political participation of individuals also increases (Putnam, 1995).

Especially after the introduction of Internet, the discussion of social capital has been divided into theory of enhancement, decline, and fusion of social capital. The theory of social capital enhancement assumes that Internet has positive impact on offline by linking the people with common interest and forming intimacy and trust between family, friends, and co-workers. In other words, due to the technical characteristics of the Internet, it has become easier to contact others and increases the indi- 
vidual's opportunities to form trust, solidarity, and interact cooperatively (Seo \& Park, 2003).

On the other hand, the theory of social capital decline assumes that Internet has negative impact on the formation of social capital. The Internet is said to cause social inequality and the loss of opportunities for face-to-face contact due to an information gap. Therefore people met on the Internet are considered to be seeking private interests rather than producing public goods and are therefore taking away from the opportunities of social participation, and the diversity and depth of the feedback you need in order to cooperation and form trust with each other. The theory explains that Internet rapidly personalizes recreational activities and blocks the formation of social capital, reduces interest in social issues, and causes a collapse of horizontal networks and hence there is a reduction in political dialog, which in turn minimizes citizen participation.

In recent years, however, a theory of compliment or fusion has been raised that emphasizes a new interpretation of the theory of social capital enhancement and decline. Fusion theory understands the Internet as interactive space of online-offline and private-public interests. And the social capital formed here is interpreted as a new form of social capital. This reflects the new reality and the characteristics of social movement on Internet. In other words, what is formulated online, the effect of are expressed offline, and the fact that even though the Internet is a place to pursue personal interests, it is also used as a tool for public benefit (Skoric \& Ng, 2009).

The discussion of fusion social capital in virtual space and in the real world emphasizes that Internet fostered social capital can evolve in a different way from traditional social capital. We should consider that on the Internet social capital forms through new kinds of social networks that are different from offline communities, yet can still be configured into a productive relationship between the virtual and real world. Based on these points, we suggest SNS is a system that can expand Internet social capital and we expect this could play an important role in the configuration of a productive relationship between virtual reality and reality.

Table 2 Acceptance as a motivation information sharing and trust is located in the appendix.

\section{Research Questions and Research Hypotheses}

\section{Empathetic Intent and the Attitudes towards Political Participation}

Studies on the effect of sharing emotions with others, emotional empathy, or the about the perceived status of others appears to be based on emotional reactions (Eisenberg \& Miller, 1987 ) as the act of helping has empathy for others as a prerequisite (eg, Batson, 1987; Batson, Klein, Highberger, \& Shaw, 1995; Batson, O'Quin, Fultz, Vanderplas, \& Isen, 1983; Baston, Early, \& Salvarani 1997 Coke et al., 1978; Toi \& Batson, 1982).

Judging from these results, a high empathetic intention in subjects indicates a high willingness to engage in pro-social behavior such as information sharing, trust, inter-group cooperation. In this study, the following research questions and hypotheses were set up.

[Question 1] Does empathetic intention fostered on SNS have a positive impact on people's attitude towards political participation?

(Hypotheses 1-1) With a higher empathetic intent the degree of information shared will be higher.
(Hypotheses 1-2) With a higher empathetic intent, the degree of inter-group cooperation will be greater.

\section{The Motivation to Belong and Attitudes towards Political Participation}

The motive to belong is a fundamental human motivation. Because humans are social animals, to belong to a group of people, and to become accepted by others is a very powerful motivation (Baumeister \& Leary, 1995). The perception of others when people meet and the extent to which we are accepted is a generally a psychological device used to gauge self-esteem (Sociometer: Leary, 2000), and when people have been accepted by others to this creates a state self-esteem which is a positive experience (Leary, Tambor, Terdal, \& Downs, 1995).

Thus we can confidently deduce that those that express a strong motivation to belong will engage in more pro-social behavior. As pro-social behavior by nature is socially desirable, it is easier for individuals to win a positive evaluation by engaging in behavior that is consider acceptable to the group. Therefore, subjects motivated by group acceptance report more prosocial behavior, namely information sharing, trust, and intergroup cooperation. In this study, the following research questions were also addressed.

[Question 2] Does the motivation to belong fostered by SNS create a positive attitude towards political participation?

(Hypotheses 2-1)When the motivation to belong is high, the extent to which individuals share information will be greater.

(Hypothesis 2-2)When the motivation to belong is high, the degree of confidence that individuals have in each other will be greater.

(Hypotheses 2-3)When the motivation to belong is high the consistency of political attitudes offline will also be high.

\section{Attitudes towards Online and Offline Political Participation}

It is a fact that a person's values have a significant impact on political attitudes. This reflects a person's actual attitude a deeper level than the online or offline political attitude presented to a group as motivated by impression management. This means that if we examine online and offline political attitudes they may not necessarily be consistent.

For example, if a person is mainly connected to an internet community that is politically conservative that person's personal attitudes may also seem conservative, but if the same person is surrounded offline by politically progressive friends he or she could also display a progressive attitude. In this case, the political attitudes that a person shows rather than his or her real attitude, but a temporarily formulated attitude to just blend in well with others and to seem to be acceptable. In this study, the following research questions and hypotheses are derived.

[Question 3] Does online and offline political participation mutually influence attitudes?

(Hypotheses 3-1) Where there is a high cognitive behavioral control displayed online, there will be a greater intent to engage in offline political action.

(Hypotheses 3-2) There will be a high correlation between online and offline political attitudes

(Hypothesis 3-3) Where there is a more positive attitude to- 
wards online political action there will also be more intent to engage in offline political action.

(Hypothesis 3-4) Where there is a more positive attitude towards offline political action there will also be more intent to engage in offline political action.

\section{Major Factors}

Table 3 Major factors is located in the appendix.

\section{Research Methods}

\section{Research Methods and the Characteristics of the Respondents}

This study was conducted using a structured questionnaire survey method. College students were selected as the target population due to the convenience of sampling. Also using standard sampling methods the researchers could easily obtain a random sample. Therefore, because the rigid measures were used, the sample in no way lacks representativeness.

However, this study has validity in statistical sampling requirements, rather than the statistical precision but finding the general trend is within expectations. In addition, college students compared to other tiers stand out because of their access to the latest media and high density of media use is a considerable factor in the selection of the sample.

In this study, hierarchical regression analysis was used. In particular, in order to remove the bias on the tendency of the individual respondents, the demographic characteristics of the respondents were entered in Step 1, as demographic variables (eg., gender, age, education, etc.), and in accordance with the hypothesis empathetic intentions or motivations were entered in step 2.

\section{Survey Configuration}

In this study, there were several factors extracted from social media (blogs, Me2day, Twitter, Facebook, Online Communities, Cyworld). Each of those factors, niche width, niche overlap, and niche advantage where used to create a 7-point scale (1 = strongly disagree, $2=$ disagree, $3=$ somewhat disagree $4=$ neutral $5=$ somewhat agree, $6=$ agree, $7=$ strongly agree).

The questions used in this study follow those of other studies of the media, Kim Gwan-gyu (2000, 2002), Kim Yu-Jeong (2002), Na Eun-young (2001, 2002), No Ki-young and Ki-Young Lee (2005), and Bae Jin-han (2001, 2003) relevant factors were extracted from these studies and restructured for use in this study. In other words, the information identified in the study, for example, gender, relationships, convenience, entertainment, personality, sociability factors are addressed by the questions adopted.

\section{Data Collection and Analysis}

The survey for this study was given on 9th October 2011 and was conducted over 11 days. When it was recalled a total of 291 college students responded to the structured self-administrated questionnaire and the information identified in previous studies, performance, social relationships, and motivation-related factors were obtained

This study is a research identifying competition among services to meet the users' satisfaction. Services chosen were ac- tively used domestic services and social network media such as: blogs, Me2day, Twitter, Facebook, Online Community, Cyworld services. In 2011 surveys were conducted on campus in order to measure levels of satisfaction or the opportunity to have a satisfactory experience through the use of SNS. The data secured was analyzed through the Statistical Package of Social Sciences, SPSS 19.

A look at the demographic characteristics of the respondents showed that there were 164 male participants (56.0\%) and 127 female participants $(43.6 \%)$ with one non-response, and the average age was 26 years old. In addition, the age range of 20 to 24 years old, 122 patients $(41.9 \%)$ was the most common.

In this paper, we sought to verification the hypothesis through hierarchical regression analysis. In particular, in order to remove the bias of the responses caused by the demographic characteristics of the individual and demographic variables in step 1 , the predictive variables for each hypothesis was set in step 2 . The hypotheses, and analysis conducted are presented as follows.

Tables 4. Measurement variable, 5. Major factors of credibility, 6. The characteristics of the respondents are located in the appendix.

\section{Hypothesis Testing}

\section{Sympathy with the Intent to Participate Politically}

Empathetic intention will be stronger the greater the extent to which information sharing occurs. Hypothesis 1 , the results are as follows:

Does empathetic intention fostered on SNS have a positive impact on people's attitude towards political participation?

(Hypotheses 1-1) With a higher empathetic intent the degree of information shared will be higher.

You will find that after controlling for the demographic variables the prediction concerning empathetic intent and information sharing proved significant; the higher the empathetic intent, the higher the degree of information sharing. The regression equation for Model 2 is as follows, and empathetic intent according to the following regression equation to predict information sharing had a significance level of $p<.001$ which is statistically significant.

$$
Y=.358 X_{1}+\varepsilon
$$

Table 7 Empathy in promoting information sharing, a hierarchical regression analysis $(n=291)$ is located in the appendix.

(Hypotheses 1-2) With a higher empathetic intent, the degree of inter-group cooperation will be greater.

For hypotheses 1-2 empathetic intention will be stronger the higher the degree of cooperation within the group, results are summarized as follows.

Empathetic intent significantly predicts the level of cooperation within a group, even after controlling for demographic variables. In other words, a high degree of empathetic intention indicates a stronger cooperation within groups. The regression equation of Model 2 is as follows, and empathetic intent according to the following regression equation can predict the degree of cooperation within the group with a significance level of $p<.001$ which is statistically significant.

$$
Y=.320 X_{1}+\varepsilon
$$


Table 8 Empathy in intergroup cooperation, a hierarchical regression analysis $(n=291)$ is located in the appendix.

\section{The Motivation to Belong and Attitudes towards Political Participation}

[Question 2] Does the motivation to belong fostered by SNS create a positive attitude towards political participation?

(Hypotheses 2-1)When the motivation to belong is high, the extent to which individuals share information will be greater.

Regarding the motivation to belong and information sharing (Hypothesis 2-1). The results are as follows: Subject motivation significantly predicted the degree of information sharing that can be seen even after controlling for demographic variables. In other words, the higher motivation to belong, the stronger the intention to share information. Therefore, the regression equation of Model 2 is as follows, and following regression equation predicts that the higher motivation to belong the greater the information sharing, with a significance level of $p<.001$ which in regression models is significant.

$$
Y=.247 X_{1}+\varepsilon
$$

Table 9 Acceptance as a motivation and the sharing of information, a hierarchical regression analysis $(n=291)$ is located in the appendix.

(Hypothesis 2-2)When the motivation to belong is high, the degree of confidence that individuals have in each other will be greater.

The results and analysis of the hypothesis regarding a high the motivation to belong, in relation to a strong degree of confidence in others $2-2$ is as follows. The motivation to belong significantly predicted the degree of confidence, even after controlling for all demographic variables.

Having a high motivation to belong indicates, a higher degree of confidence in the other party. The regression equation of Model 2 is as follows, and the motivation to belong, according to the following regression equation predicts that the higher the score, the higher the degree of confidence, with a signifycance level of $p<.001$ which in the regression models is significant.

$$
Y=.293 X_{1}+\varepsilon
$$

Table 10 Acceptance as a motivation and confidence in others, a hierarchical regression analysis $(n=291)$ is located in the appendix.

(Hypotheses 2-3)When the motivation to belong is high the consistency of political attitudes offline will also be high.

On higher motivation to belong and greater consistency of offline political attitudes (hypotheses 2-3) the results are as follow. The motivation to belong scores high after controlling for the demographic variables as well as the consistency of political attitudes as predicted.

However, in relation to the expression of offline political attitudes this was less consistent. This interpretation, however, is due to the description of the model variance and is not significant in the interpretation of the results. Therefore the regression equation of Model 2 is as follows, and the motivation to belong, according to the following regression equation predicts that the higher the score, the higher the consistency of offline political attitudes, with a significance level of $p<.01$ which in the regression models is significant.

$$
Y=-.176 X_{1}+\varepsilon
$$

Table 11 Motivation and offline political attitudes, a hierarchical regression analysis $(n=291)$ is located in the appendix.

\section{Attitudes towards Online and Offline Political Participation}

[Question 3] Do online and offline political participation mutually influence attitudes?

(Hypotheses 3-1) Where there is a high cognitive behavioral control displayed online, there will be a greater intent to engage in offline political action.

On high online cognitive behavioral control, and a high degree of offline political action hypothesis 3-1 the higher the results are as follows:

Information-sharing scores significantly predict offline political action intentions which can be seen even after controlling demographic variables. Therefore, the higher level of information sharing through SNS, the higher the flow of offline political behavior. In addition, offline political trust scores significantly predicted behavioral intentions which can be seen even after controlling for demographic variables; in other words, the higher the level of trust on SNS, the greater the intent to engage in offline political action.

Therefore, under the assumption that information sharing and trust correlate to intent to engage in offline action, the relation to perceived behavioral control supports hypothesis 3-1.

Table 12 Offline political behavior and information sharing, a hierarchical regression analysis $(n=291)$ is located in the appendix.

Table13 Trust and offline political action, a hierarchical regression analysis $(n=291)$ is located in the appendix.

(Hypotheses 3-2) There will be a high correlation between online and offline political attitudes

The results of the analysis on the correlation of political attitudes in the online, offline (hypothesis 3-2) are as follows. Online and offline score regarding political attitudes display a static correlation that can be seen that significant. A consistent tendency online political attitudes and offline political attitudes has been observed.

Table 14 Online and offline political attitudes, correlation analysis $(n=291)$ is located in the appendix.

Table 15 Online political attitudes and offline political attitudes, a hierarchical regression analysis $(n=291)$ is located in the appendix.

In addition, you can see that online political attitude scores to predict offline political attitude scores after controlling demographic variables are accurate. Therefore, the more positive attitudes are toward online politics, the more offline political attitudes are positive. In the end, hypothesis 3-2 was supported.

(Hypothesis 3-3) Where there is a more positive attitude towards online political action there will also be more intent to engage in offline political action.

On the relationship between positive online attitudes toward politics and greater offline political action (hypothesis 3-2) An analysis of the results are summarized as follows.

Table 16 Online political attitudes and offline political behavior, a hierarchical regression analysis $(n=291)$ is located in the appendix.

Online political attitude scores significantly predicted intended offline political action which can be seen after controlling for demographic variables. Therefore, the more positive the online political attitudes the greater the offline intention to engage in political action is observed. Hypothesis 3-3 was sup- 
ported.

(Hypothesis 3-4) Where there is a more positive attitude towards offline political action there will also be more intent to engage in offline political action.

On the relationship between more positive offline attitudes toward politics and greater offline political action (hypothesis $3-4)$, an analysis of the results is as follows.

Table 17 Offline political attitudes and political behavior, a hierarchical regression analysis $(n=291)$ is located in the appendix.

Offline political attitude scores significantly predict offline political action which can be seen after controlling for demographic variables. Offline political attitudes had an effect on intended offline political action. Therefore, hypothesis 3-4 was supported.

\section{Conclusion and Implications}

\section{The Findings}

The impact of this study on political participation, trust and information sharing through SNS fostered empathetic intention and motivation, is comprehensively reviewed. The results can be summarized as follows.

First, a high degree of empathic intention is required to share information. Second, the higher the degree of cooperation within a group, the stronger the empathetic intention is. Third, a strong motivation to belong correlates to a high degree of information sharing. Fourth, the higher the degree of confidence one has in others the higher the motivation to belong is. Finally, a consistent political attitude correlates to a high motivation to belong. The offline hypothesis was rejected.

As you can see, the strong findings from first to fourth indicate that the connection between high empathic intent and pro-social behavioral tendency was supported to some extent by the motivation to belong to a much higher degree than higher reasoning. This is just as in the offline world, therefore, SNS is significantly predictive of pro-social behavioral tendencies as they appear online as empathetic intention and motivation.

Sixth, the higher the online/offline cognitive behavioral control is, the higher the intention to act politically. Seventh, there is a high correlation between online and offline political attitudes. Eighth, there is a close relationship between online/offline political attitudes and intended political action. Ninth, the more positive the online/offline political attitude is, the higher the intention to act politically. It is clear that the political attitude that can be formed through social media have a considerable impact on behavioral intention, even offline.

Table 18 The impact of the dependent variable on step 2 and 3 (hierarchical regression analysis) is located in the appendix.

\section{The Implications of the Study}

The results of this study show that people act in accordance to their plans in both cyberspace and real space, and this can be explained. The implications of this present study can be summarized as follows.

The empathetic intentions fostered by SNS tend to affect the experience of empathy and confidence respectively. We know a priori that the sympathetic experience of the subjects affect the behavior in actual reality.

This together with the results of the research on experience observed by Hunt (2007), enables us to look at the results of this research on the relationship between empathy and SNS in the same vein as Raymond, et al. (2009).

The correlation that exists between real political participation and trust and empathy through SNS is consistent with the existing research results.

These results are particularly relevant as self-disclosure does more than simply provide more information but it also appears to have a positive influence on the experience of empathy, as prior research on self exposure (Jourard, 1964 As Shapiro \& Swenson, 1977) discussed. Based on this understanding, to candidly confide one's experience and feelings is a process of understanding the true self, and this seems to create more empathy as a result.

In addition, it appears that by increasing the amount of information entrusted to others and as the sharing of experiences increase so does the degree of sympathy fostered on SNS. Specifically, the elements of imagining another perspective, sympathetic interest, social trust and interpersonal trust were each influenced similarly. When we consider claims about the relationship between empathy and pro-social behavior (Hoffman, 1986; Batson, Ahmad, Lishner, \& Tsang, 2002), and emotional support and relationship formation (Weber, Johnson, \& Corrigan, 2004), these results are consistent the research. We can see that the experience of empathy has a positive impact on the formation of positive relationships with others.

\section{REFERENCES}

Bae, J.-H. (2001). Meeting and recognizing the suitability of the mobile phone as an interpersonal communication medium. Korea press Journal, 45, 160-188

Bae, J.-H. (2003). The impact of face-to-face interpersonal communication media used in the new communications environment. Korea Press Gazette, 23, 47-77.

Kang, N.-W. (2004). Study on the impact of the Internet and using mass media to participate. Korea Press Gazette, 48, 116-143.

Kim, K.-G. (2000). Interpersonal impression formation in CMC in exploratory research. Cyber Communication Gazette, 5-29.

Kim, K.-G. (2002). A comparison of human relationships through computer-mediated communication, relationships and real space. Korea $\mathrm{Na}$ tional Journal, 16, 73-109.

Kim, M.-J., \& Choi, Y,-J. (2012). The impact of online and offline relationships formed on smartphones via Twitter. Korea National Journal, 26, 43-82.

Kim, Y.-J. (2002). Attitudes of users according to media selection and the use of media. Broadcasting Gazette, 16, 105-135.

Na, E.-Y. (2001). A study affecting the adoption of mobile phone, mobile phone communications, and media properties. Korea Press Journal, $45,189-228$

Na, E.-Y. (2002). Women's new media use and its value. Korea National Gazette, 16, 77-115.

No, K.-Y., \& Lee, M.-Y. (2005). Study on competition in the medium of the blog. Korea press Journal, 49, 318-345.

Park, S.-H. (2004). Empathetic schools yesterday and today. Hakjisa.

Seo, J.-W., \& Park, H.-B. (2003). Internet use and social capital: the possibilities of the cyber-community to form of social capital. Policy Studies, 12, pp. 27-49.

Ajzen, I. (1985). From intention to actions: A theory of planned behavior. In J. Kuhl, \& J. Beckman (Eds.), Action control: From cognition to behavior (pp. 11-39). New York: Springer-Verlag.

Bandura, A. (1977). Self-efficacy: Toward a unifying theory of behavioral change. Psychological Review, 84, 191-215. doi:10.1037/0033-295X.84.2.191

Batson, C. D. (1987). Prosocial motivation: Is it ever truly altruistic? In L. Berkowitz (Ed.), Advances in experimental social psychology (pp. 65-122). San Diego, CA: Academic Press. 
Batson, C. D., Ahmad, N., \& Tsang, J. (2002). Four motives for community involvement. Journal of Social Issues, 58, 429-445. doi:10.1111/1540-4560.00269

Batson, C. D., Early, S., \& Salvarani, G. (1997). Perspective taking: Imagining how another feels versus imagining how you would feel. Personality and Social Psychology Bulletin, 23, 751-758. doi: $10.1177 / 0146167297237008$

Batson, C. D., Klein, T. R., Highberger, L., \& Shaw, L. L. (1995). Immorality from empathy-induced altruism: When compassion and justice conflict. Journal of Personality and Social Psychology, 68, 10421054. doi:10.1037/0022-3514.68.6.1042

Batson, C. D., O’Quin, K., Fultz, J., Vanderplas, M., \& Isen, A. (1983). Self-reported distress and empathy and egoistic versus altruistic motivation for helping. Journal of Personality and Social Psychology, 45, 706-718. doi:10.1037/0022-3514.45.3.706

Batson, C. D., Sager, K., Garst, E., Kang M., Rubchinsky, K., \& Dawson, K. (1997). Is empathy-induced helping due to self-other merging? Journal of Personality and Social Psychology, 73, 495-509. doi:10.1037/0022-3514.73.3.495

Baumeister, R. F., \& Leary, M. R. (1995). The need to belong: Desire for interpersonal attachments as a fundamental human motivation. Psychological Bulletin, 117, 497-529. doi:10.1037/0033-2909.117.3.497

Brehm, J., \& Rhan, W. M. (1997). Individual level evidence for the causes and consequences of social capital. American Journal of Political Science, 41, 999-1023. doi:10.2307/2111684

Coke, J. S., Batson, C. D., \& McDavis, K. (1978). Empathic mediation of helping: A two-stage model. Journal of Personality and Social Psychology, 36, 752-766. doi:10.1037/0022-3514.36.7.752

Davis, M. H. (1983). Measuring individual differences in empathy: Evidence for a multidimensional approach. Journal of Personality and Social Psychology, 44, 113-126. doi:10.1037/0022-3514.44.1.113

Davis, M. H., Conklin, L., Smith, A., \& Luce, C. (1996). Effect of perspective taking on the cognitive representation of persons: A merging of self and other. Journal of Personality and Social Psychology, 70, 713-726. doi:10.1037/0022-3514.70.4.713

Eisenberg, N., \& Fabes, R. A. (1990). Empathy: Conceptualization, measurement, and relation to prosocial behavior. Motivation and Emotion, 14, 131-149. doi:10.1007/BF00991640

Eisenberg, N., \& Miller, P. A. (1987). The relation of empathy to prosocial and related behaviors. Psychological Bulletin, 101, 91-119. doi:10.1037/0033-2909.101.1.91

Fukuyama, F. (1999). The great disruption: Human nature and the ceconstruction of social order. New York: Free Press.

Galinsky, A. D., Ku, G., \& Wang, C. S. (2005). Perspective taking and self-other overlap: Fostering social bonds and facilitating social coordination. Group Process and Intergroup Relations, 8, 109-124. doi: $10.1177 / 1368430205051060$

Galinsky, A. D., \& Moskowitz, G. B. (2000). Perspective-taking: Decreasing stereotype expression, stereotype accessibility, and in-group favorism. Journal of Personality and Social Psychology, 78, 708-724. doi: $10.1037 / 0022-3514.78 .4 .708$

Giddens, A. (1990). The consequence of modernity. Standford, CA: Standford University Press.

Hodges, S. D., Kiel, K. J., Kramer, A. D. I., Veach, D., \& Villanueva, B. R. (2010). Giving birth to empathy: The effects of similar experience on empathic accuracy, empathic concern, and perceived empathy. Personality and Social Psychology Bulletin, 36, 398-409.

doi: $10.1177 / 0146167209350326$
Hoffman (1986).Effective teaching of reading: Research and practice. Newark, DE: International Reading Association.

Ickes, W. (1993). Empathic accuracy. Journal of Personality, 61, 587610. doi:10.1111/j.1467-6494.1993.tb00783.x

Jourard, S. M (1964). The transparent self. New York: Van Nostrand.

$\mathrm{Ku}, \mathrm{G} .$, Wang, C., \& Gallinsky, A. (2010). Perception through a perspective-taking lens. Journal of Experimental Social Psychology, 46, 792-798. doi:10.1016/j.jesp.2010.04.001

Leary, M. (2000). The nature and function of self-esteem: Sociometer theory. Burlington, MA: Elsevier.

Leary, M., Tambor, E., Terdal, S., \& Downs, D. (1995). Self-esteem as an interpersonal monitor: The sociometer hypothesis. Journal of Personality and Social Psychology, 68, 518-530.

doi:10.1037/0022-3514.68.3.518

Lipps, T. (1907). Das wissen von fremden ichen. Psychologischen Untersuchungen, 1, 694-722.

Markus, H., \& Zajonc, R. B. (1985). The cognitive perspective in social psychology. In G. Lindzey \& E. Aronson (Eds.), The handbook of social psychology (3rd Ed., pp. 137-230). New York: Random House.

Putnam, R. D. (1995). Tuning in, turning out: The strange disappearance of social capital in America. Political Science and Politics, 27, 6483.

Preston, S. D., \& Hofelich, A. J. (2012). The many faces of empathy: Parsing empathic phenomena through a proximate, dynamic-systems view of representing the other in the self. Emotion Review, 4, 24-33.

Raymond, et al. (2009). Planet-planet scattering in planetesimal disks. The Astrophysical Journal Letters, 699, L88-L92.

doi:10.1088/0004-637X/699/2/L88

Regan, D., \& Totten, J. (1975). Empathy and attribution: Turning observers into actors. Journal of Personality and Social Psychology, 32 850-856. doi:10.1037/0022-3514.32.5.850

Shapiro, A., \& Swenson, C. H. (1977). Self-disclosure as a function of self-concept and sex. Journal of Personality Assessment, 41, 144-149. doi:10.1207/s15327752jpa4102 4

Simpson, J. A., Orina, M. M., \& Ickes, W. (2003). When accuracy hurts, and when it helps: A test of the empathic accuracy model in martial interactions. Journal of Personality and Social Psychology, 85, 881-893. doi:10.1037/0022-3514.85.5.881

Skoric, M. M., Ying, D., \& Ng, Y. (2009). Bowling online, not alone: Online social capital and political participation in Singapore. Journal of Computer-Mediated Communication, 14, 411-423.

doi:10.1111/j.1083-6101.2009.01447.x

Stern, S. (2002). Sexual selves on the world wide web: Adolescent girls' home pages as sites for sexual self-expression. In J. D. Brown, J. R. Steele, \& K. Walsh-Childers (Eds.), Sexual teens, sexual media: Investigation media's influence on adolescent sexuality (pp. 265-285). Hillsdale, NJ: Lawrence Erlbaum Associates.

Toi, M., \& Batson, C. D. (1982). More evidence that empathy is a source of altruistic motivation. Journal of Personality and Social Psychology, 43, 281-292. doi:10.1037/0022-3514.43.2.281

Weber, K., Johnson, A., \& Corrigan, M. (2004). Communicating emotional support and its relationship to feelings of being understood, trust, and self-disclosure. Communication Research Reports, 21, 316-323. doi:10.1080/08824090409359994

Wispé, L. (1986). The distinction between sympathy and empathy: To call forth a concept, a word is needed. Journal of Personality and Social Psychology, 50, 314-321. doi:10.1037/0022-3514.50.2.314 


\section{S. Y. LEE, S. H. KWEON}

\section{Appendix}

Table 1.

Sympathy in relation to attitude and intention towards political participation.

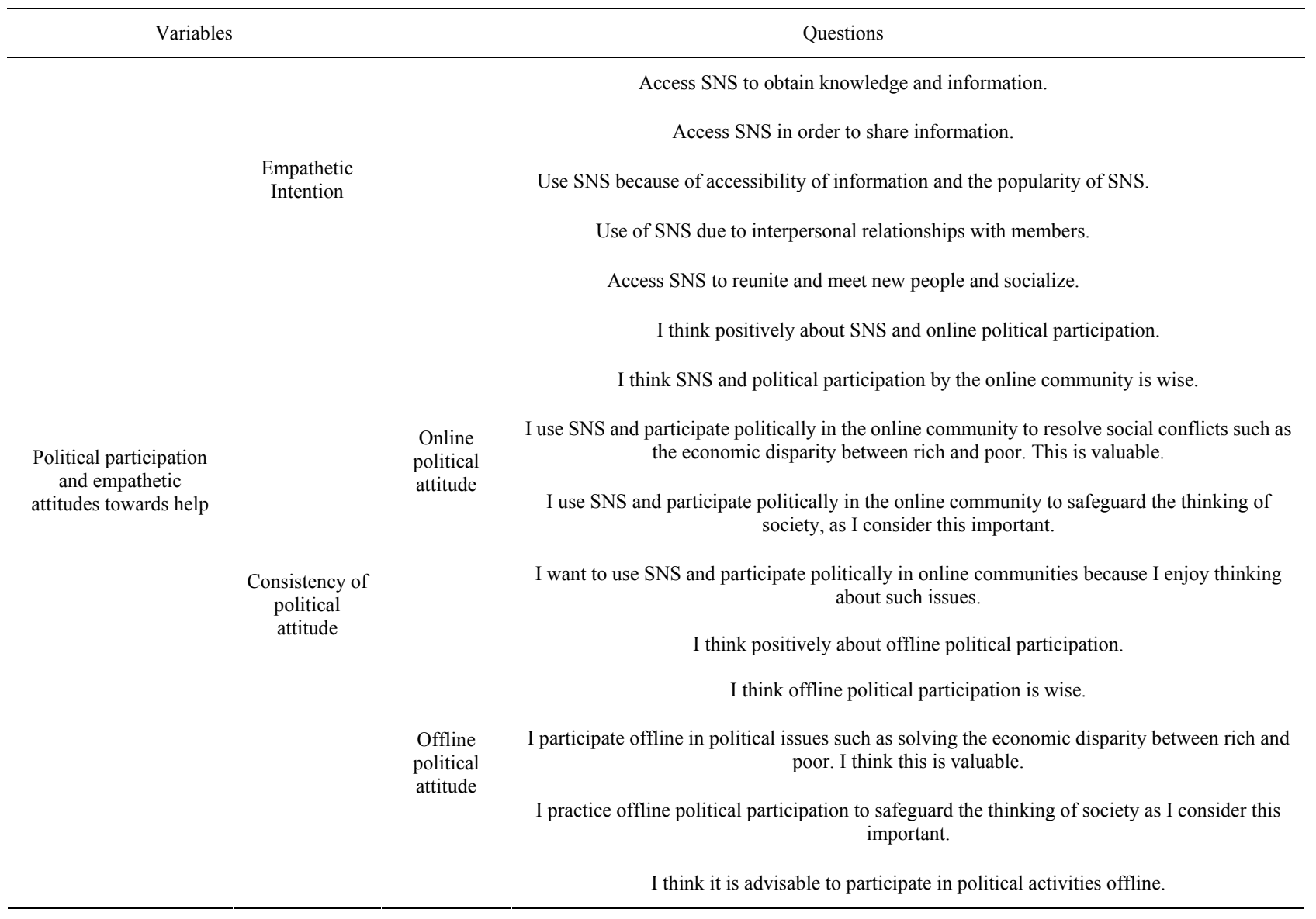

Table 2.

Acceptance as a motivation, information sharing, and trust.

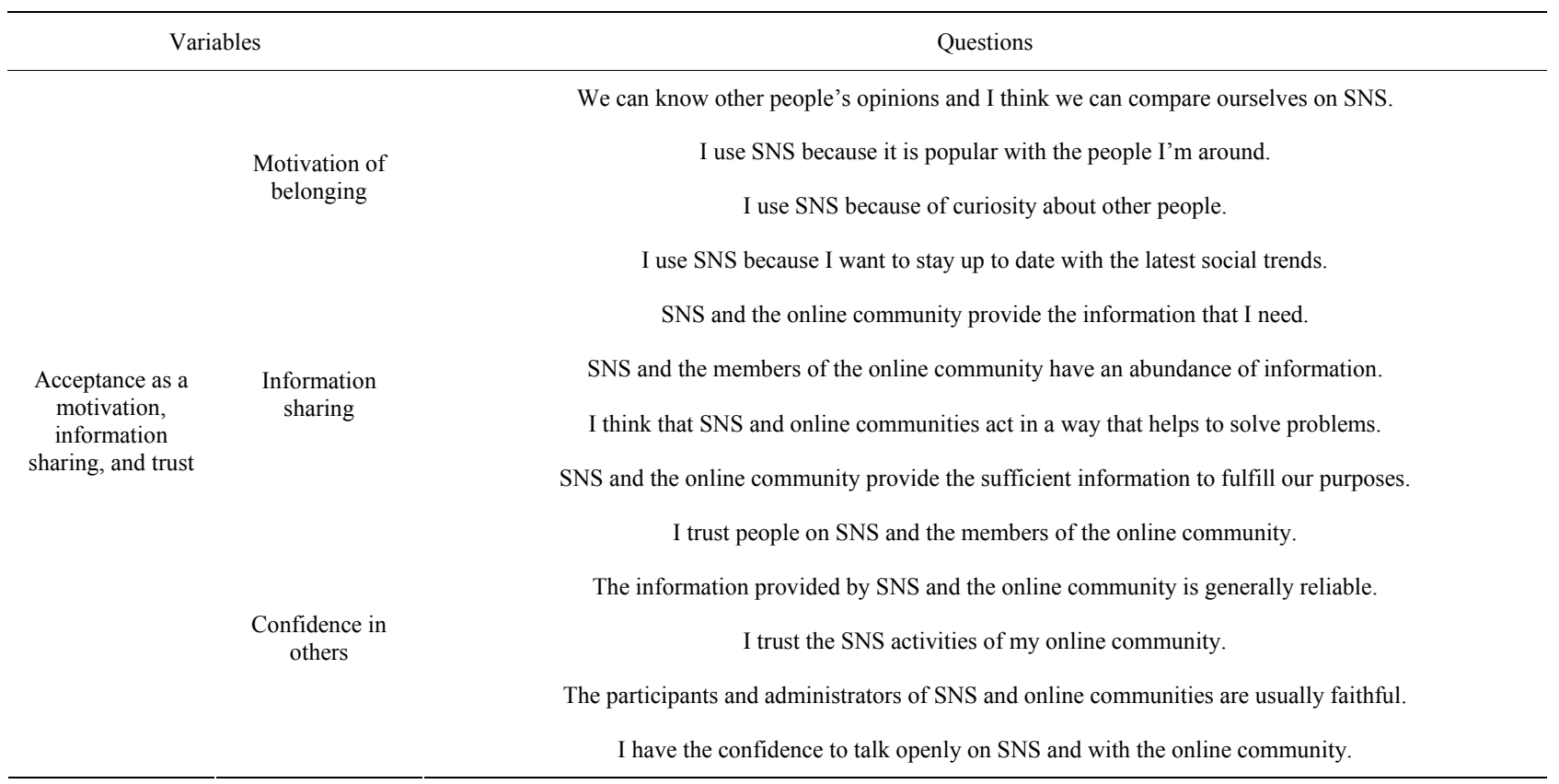




\section{S. Y. LEE, S. H. KWEON}

Table 3.

Major factors.

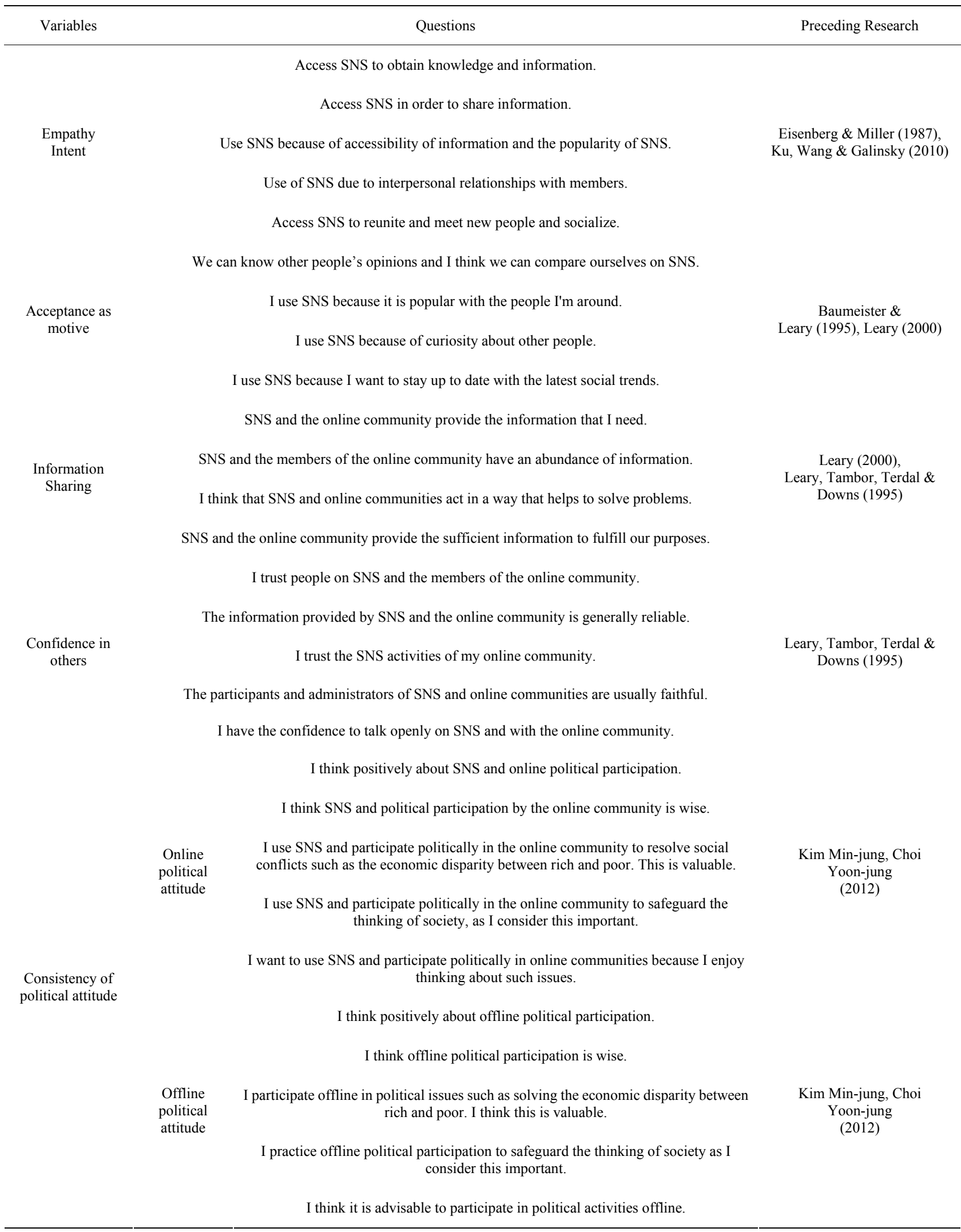

Measurement is a 7-point scale $(1=$ does not do this at all/does not $/$ not at all to $7=$ very true/very often uses / Strongly Agree $)$. 


\section{S. Y. LEE, S. H. KWEON}

Table 4.

Measurement variable.

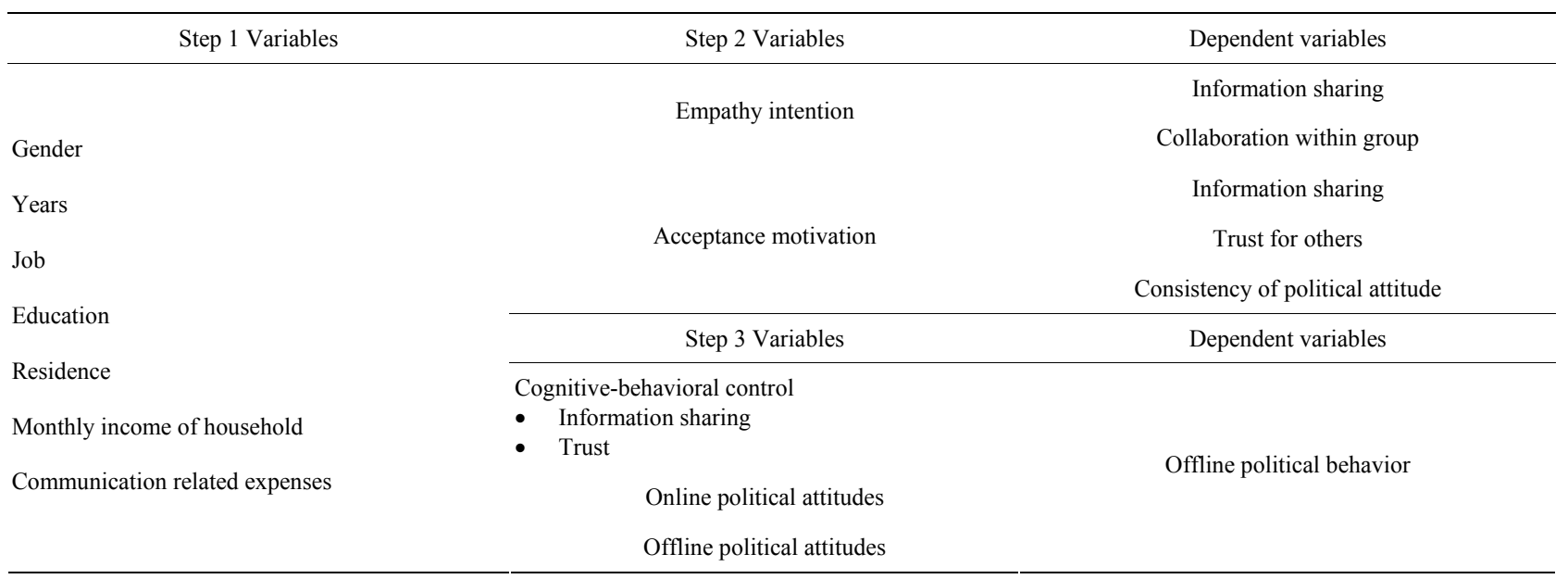

Table 5.

Major factors of credibility.

\begin{tabular}{|c|c|c|}
\hline \multicolumn{2}{|c|}{ Variables } & Credibility \\
\hline \multicolumn{2}{|c|}{ Empathy intention } & .90 \\
\hline \multicolumn{2}{|c|}{ Acceptance motivation } & .85 \\
\hline \multicolumn{2}{|c|}{ Information sharing } & .88 \\
\hline \multicolumn{2}{|c|}{ Trust for others } & .90 \\
\hline \multirow{2}{*}{ Consistency of political attitudes } & Online political attitudes & .96 \\
\hline & Offline political attitudes & .95 \\
\hline
\end{tabular}

Table 6.

The characteristics of the respondents.

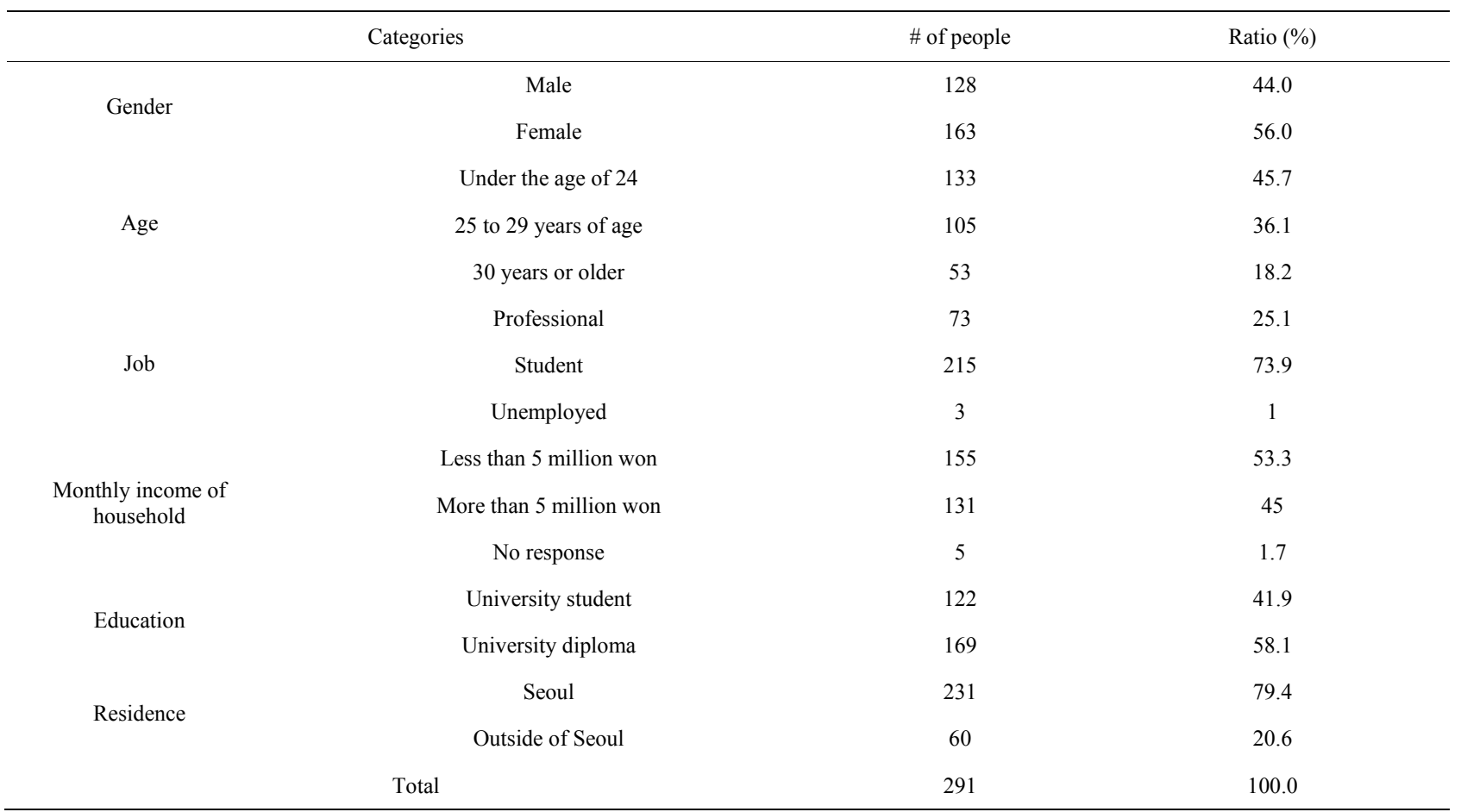




\section{S. Y. LEE, S. H. KWEON}

Table 7.

Empathy in promoting information sharing, a hierarchical regression analysis $(\mathrm{n}=291)$.

\begin{tabular}{|c|c|c|c|c|c|c|}
\hline Model & & $\beta$ & $R^{2}$ & $\mathrm{~F}$ & $R^{2}$ change & F change \\
\hline \multirow[t]{7}{*}{ Set1 } & Gender & .088 & & & & \\
\hline & Age & .004 & & & & \\
\hline & Job & $.174^{* *}$ & & & & \\
\hline & Education & -.101 & & & & \\
\hline & Residence & -.027 & & & & \\
\hline & Household monthly income & .000 & & & & \\
\hline & Communication related expenses & $.113^{\dagger}$ & .049 & $2.09^{*}$ & & \\
\hline Set2 & Empathy intention & $.358^{* * *}$ & .176 & $7.513^{* * *}$ & .127 & 43.32 \\
\hline
\end{tabular}

Dependent variable: information sharing; ${ }^{*} p<.05,{ }^{* *} p<.01,{ }^{* * *} p<.001$.

Table 8.

Empathy in intergroup cooperation, a hierarchical regression analysis $(\mathrm{n}=291)$.

\begin{tabular}{|c|c|c|c|c|c|c|}
\hline Model & & $\beta$ & $R^{2}$ & $\mathrm{~F}$ & $R^{2}$ change & $F$ change \\
\hline \multirow[t]{7}{*}{ Set1 } & Gender & $.135^{*}$ & & & & \\
\hline & Age & $.190^{*}$ & & & & \\
\hline & Job & $.250^{* * *}$ & & & & \\
\hline & Education & -.027 & & & & \\
\hline & Residence & -.055 & & & & \\
\hline & Household monthly income & .028 & & & & \\
\hline & Communication related expenses & .012 & .057 & $2.47^{* *}$ & & \\
\hline Set2 & Empathy intention & $.320^{* * *}$ & .159 & $6.65^{* * *}$ & .101 & 33.89 \\
\hline
\end{tabular}

Dependent variable: cooperation within the group; ${ }^{*} p<.05,{ }^{* *} p<.01,{ }^{* * *} p<.001$.

Table 9.

Acceptance as a motivation and the sharing of information, a hierarchical regression analysis $(n=291)$.

\begin{tabular}{|c|c|c|c|c|c|c|}
\hline Model & & $\beta$ & $R^{2}$ & $\mathrm{~F}$ & $R^{2}$ change & $F$ change \\
\hline \multirow[t]{7}{*}{ Set1 } & Gender & .088 & & & & \\
\hline & Age & .004 & & & & \\
\hline & Job & $.174^{* *}$ & & & & \\
\hline & Education & -.101 & & & & \\
\hline & Residence & -.027 & & & & \\
\hline & Household monthly income & .000 & & & & \\
\hline & Communication related expenses & $.113^{\dagger}$ & .049 & $2.086^{*}$ & & \\
\hline Set2 & Acceptance motivation & $.247^{* * *}$ & .109 & $4.30^{* * *}$ & .060 & 18.88 \\
\hline
\end{tabular}

Dependent variable: information sharing; ${ }^{*} p<.05,{ }^{* *} p<.01,{ }^{* * *} p<.001$. 


\section{S. Y. LEE, S. H. KWEON}

Table 10.

Acceptance as a motivation and confidence in others, a hierarchical regression analysis $(n=291)$.

\begin{tabular}{|c|c|c|c|c|c|c|}
\hline Model & & $\beta$ & $R^{2}$ & $\mathrm{~F}$ & $R^{2}$ change & $F$ change \\
\hline \multirow[t]{7}{*}{ Set1 } & Gender & $.145^{*}$ & & & & \\
\hline & Age & .131 & & & & \\
\hline & Job & $.264^{* * *}$ & & & & \\
\hline & Education & -.035 & & & & \\
\hline & Residence & -.058 & & & & \\
\hline & Household monthly income & -.032 & & & & \\
\hline & Communication related expenses & $.108^{\dagger}$ & .071 & $3.107^{* *}$ & & \\
\hline Set2 & Acceptance motivation & $.293^{* * *}$ & .155 & $6.487^{* * *}$ & .084 & 28.061 \\
\hline
\end{tabular}

Dependent variable: confidence in others; ${ }^{*} p<.05,{ }^{* *} p<.01,{ }^{* * *} p<.001$.

Table 11.

Motivation and offline political attitudes, a hierarchical regression analysis $(\mathrm{n}=291)$.

\begin{tabular}{|c|c|c|c|c|c|c|}
\hline Model & & $\beta$ & $R^{2}$ & $\mathrm{~F}$ & $R^{2}$ change & F change \\
\hline \multirow[t]{7}{*}{ Set1 } & Gender & -.038 & & & & \\
\hline & Age & -.100 & & & & \\
\hline & Job & .002 & & & & \\
\hline & Education & .036 & & & & \\
\hline & Residence & -.029 & & & & \\
\hline & Household monthly income & -.024 & & & & \\
\hline & Communication related expenses & .084 & .015 & .603 & & \\
\hline Set2 & Acceptance motivation & $-.176^{* *}$ & .045 & 1.663 & .030 & 8.96 \\
\hline
\end{tabular}

Dependent variables: offline political attitudes; ${ }^{*} p<.05,{ }^{* *} p<.01,{ }^{* * *} p<.001$.

Table 12.

Offline political behavior and information sharing, a hierarchical regression analysis $(n=291)$.

\begin{tabular}{|c|c|c|c|c|c|c|}
\hline \multirow{2}{*}{ Model } & & \multicolumn{2}{|c|}{ Non-standardized coefficients } & \multirow{2}{*}{$\begin{array}{c}\text { Standardized coefficients } \\
\text { Beta }\end{array}$} & \multirow{2}{*}{$\mathrm{t}$} & \multirow{2}{*}{$\begin{array}{l}\text { Significant } \\
\text { probability }\end{array}$} \\
\hline & & B & Standard error & & & \\
\hline \multirow[t]{8}{*}{1} & (Constant) & 2.457 & .851 & & 2.886 & .004 \\
\hline & Gender & -.117 & .126 & -.064 & -.930 & .353 \\
\hline & Age & .036 & .019 & .149 & 1.902 & .058 \\
\hline & Job & .067 & .046 & .098 & 1.450 & .148 \\
\hline & Education & -.026 & .087 & -.020 & -.294 & .769 \\
\hline & Residence & -.010 & .027 & -.021 & -.357 & .721 \\
\hline & Household monthly income & -.001 & .008 & -.010 & -.178 & .859 \\
\hline & $\begin{array}{c}\text { Communication related } \\
\text { expenses }\end{array}$ & .006 & .015 & .022 & .374 & .709 \\
\hline 2 & Information Sharing & .226 & .077 & .174 & 2.924 & .004 \\
\hline
\end{tabular}

Dependent variable: offline political behavior. 


\section{S. Y. LEE, S. H. KWEON}

Table13.

Trust and offline political action, a hierarchical regression analysis $(\mathrm{n}=291)$.

\begin{tabular}{|c|c|c|c|c|c|c|}
\hline \multirow{2}{*}{ Model } & & \multicolumn{2}{|c|}{ Non-standardized coefficients } & \multirow{2}{*}{$\frac{\text { Standardized coefficients }}{\text { Beta }}$} & \multirow{2}{*}{$\mathrm{t}$} & \multirow{2}{*}{ Significant probability } \\
\hline & & B & Standard error & & & \\
\hline \multirow[t]{8}{*}{1} & (Constant) & 2.457 & .851 & & 2.886 & .004 \\
\hline & Gender & -.117 & .126 & -.064 & -.930 & .353 \\
\hline & Age () & .036 & .019 & .149 & 1.902 & .058 \\
\hline & Job & .067 & .046 & .098 & 1.450 & .148 \\
\hline & Education & -.026 & .087 & -.020 & -.294 & .769 \\
\hline & Residence & -.010 & .027 & -.021 & -.357 & .721 \\
\hline & Household monthly income & -.001 & .008 & -.010 & -.178 & .859 \\
\hline & Communication related expenses & .006 & .015 & .022 & .374 & .709 \\
\hline 2 & Reliance & .236 & .082 & .174 & 2.869 & .004 \\
\hline
\end{tabular}

Dependent variable: Offline political behavior.

Table 14.

Online and offline political attitudes, correlation analysis $(n=291)$.

\begin{tabular}{ccc}
\hline & Online political attitudes & Offline political attitudes \\
\hline Online political attitudes & 1 & $.523^{* *}$ \\
Offline political attitudes & $.523^{* *}$ & 1 \\
\hline
\end{tabular}
${ }^{* *} p<.01$.

Table 15.

Online political attitudes and offline political attitudes, a hierarchical regression analysis $(n=291)$.

\begin{tabular}{|c|c|c|c|c|c|c|}
\hline \multirow{2}{*}{ Model } & & \multicolumn{2}{|c|}{ Non-standardized coefficients } & \multirow{2}{*}{$\frac{\text { Standardized coefficients }}{\text { Beta }}$} & \multirow{2}{*}{$\mathrm{t}$} & \multirow{2}{*}{ Significant probability } \\
\hline & & $\mathrm{B}$ & Standard error & & & \\
\hline \multirow[t]{8}{*}{1} & (Constant) & 3.391 & .777 & & 4.366 & .000 \\
\hline & Gender & .029 & .115 & .017 & .252 & .801 \\
\hline & Age () & .031 & .017 & .139 & 1.776 & .077 \\
\hline & Job & .081 & .042 & .132 & 1.935 & .054 \\
\hline & Education & -.040 & .080 & -.034 & -.507 & .612 \\
\hline & Residence & -.004 & .025 & -.009 & -.152 & .879 \\
\hline & Household monthly income & -.005 & .007 & -.041 & -.688 & .492 \\
\hline & Communication related expenses & .007 & .013 & .032 & .532 & .595 \\
\hline 2 & Online political attitudes & .467 & .046 & .522 & 10.178 & .000 \\
\hline
\end{tabular}

Dependent variable: Offline political behavior and attitude.

Table 16.

Online political attitudes and offline political behavior, a hierarchical regression analysis $(n=291)$.

\begin{tabular}{|c|c|c|c|c|c|c|}
\hline \multirow{2}{*}{ Model } & & \multicolumn{2}{|c|}{ Non-standardized coefficients } & \multirow{2}{*}{$\frac{\text { Standardized coefficients }}{\text { Beta }}$} & \multirow{2}{*}{$\mathrm{t}$} & \multirow{2}{*}{ Significant probability } \\
\hline & & B & Standard error & & & \\
\hline \multirow[t]{8}{*}{1} & (Constant) & 2.457 & .851 & & 2.886 & .004 \\
\hline & Gender & -.117 & .126 & -.064 & -.930 & .353 \\
\hline & Age () & .036 & .019 & .149 & 1.902 & .058 \\
\hline & Job & .067 & .046 & .098 & 1.450 & .148 \\
\hline & Education & -.026 & .087 & -.020 & -.294 & .769 \\
\hline & Residence & -.010 & .027 & -.021 & -.357 & .721 \\
\hline & Household monthly income & -.001 & .008 & -.010 & -.178 & .859 \\
\hline & Communication related expenses & .006 & .015 & .022 & .374 & .709 \\
\hline 2 & Online political attitudes & .504 & .051 & .511 & 9.978 & .000 \\
\hline
\end{tabular}

Dependent variable: Offline political behavior. 


\section{S. Y. LEE, S. H. KWEON}

Table 17.

Offline political attitudes and political behavior, a hierarchical regression analysis $(\mathrm{n}=291)$.

\begin{tabular}{|c|c|c|c|c|c|c|}
\hline \multirow{2}{*}{ Model } & & \multicolumn{2}{|c|}{ Non-standardized coefficients } & \multirow{2}{*}{$\frac{\text { Standardized coefficients }}{\text { Beta }}$} & \multirow{2}{*}{$\mathrm{t}$} & \multirow{2}{*}{ Significant probability } \\
\hline & & B & Standard error & & & \\
\hline \multirow[t]{8}{*}{1} & (Constant) & 2.457 & .851 & & 2.886 & .004 \\
\hline & Gender & -.117 & .126 & -.064 & -.930 & .353 \\
\hline & Age () & .036 & .019 & .149 & 1.902 & .058 \\
\hline & Job & .067 & .046 & .098 & 1.450 & .148 \\
\hline & Education & -.026 & .087 & -.020 & -.294 & .769 \\
\hline & Residence & -.010 & .027 & -.021 & -.357 & .721 \\
\hline & Household monthly income & -.001 & .008 & -.010 & -.178 & .859 \\
\hline & Communication related expenses & .006 & .015 & .022 & .374 & .709 \\
\hline 2 & Offline political attitudes & 676 & .052 & .613 & 13.115 & .000 \\
\hline
\end{tabular}

Dependent variable: Offline political behavior.

Table 18.

The impact of the dependent variable on step 2 and 3 (hierarchical regression analysis).

\begin{tabular}{|c|c|c|c|c|}
\hline & & Information sharing & Intergroup collaboration & \\
\hline & Empathy & $.358^{* * *}$ & $.320^{* * *}$ & \\
\hline \multirow{5}{*}{$\begin{array}{c}\text { Step } 2 \\
\text { Variables }\end{array}$} & & Information sharing & Trust for others & Online/offline political attitudes \\
\hline & $\begin{array}{l}\text { Acceptance } \\
\text { motivation }\end{array}$ & $.247^{* * *}$ & $.293^{* * *}$ & $-.176^{* *}$ \\
\hline & & \multicolumn{2}{|c|}{ Attitude to offline political behavior } & Offline political behavior \\
\hline & Information sharing & & & $.226^{* *}$ \\
\hline & Trust & & & $.236^{* *}$ \\
\hline \multirow[t]{2}{*}{$\begin{array}{c}\text { Step } 3 \\
\text { variables }\end{array}$} & $\begin{array}{l}\text { Online political } \\
\text { attitudes }\end{array}$ & \multirow{2}{*}{\multicolumn{2}{|c|}{$.467^{* * *}$}} & $.504^{* * *}$ \\
\hline & $\begin{array}{l}\text { Offline political } \\
\text { attitudes }\end{array}$ & & & $.676^{* * *}$ \\
\hline
\end{tabular}

Dependent variables: information sharing, intergroup co-operation, trust for others, online/offline political attitudes, attitudes to offline political action, offline political behavior. Note: The values given are the regression coefficients $(\beta) .{ }^{*} p<.05,{ }^{* *} p<.01,{ }^{* * *} p<.001$. 